\title{
The analysis of free writing, vocabulary, and dyslexia in English as a native and foreign language (English vs. Polish students)
}

\section{BACKGROUND}

The aim of our study was to compare free writing skills in English as a native language and a foreign language (in English and Polish students respectively). English and Polish have dissimilar orthographies in terms of grapheme-phoneme correspondence rules that is why we were curious to examine whether native and foreign speakers of English exhibit some similarities and/or differences in terms of writing and vocabulary, controlling the dyslexia factor at the same time.

\section{PARTICIPANTS AND PROCEDURE}

28 English junior high school students: 13 with dyslexia (ED), 15 without (END), and 32 Polish junior high school students: 16 with dyslexia (PD) and 16 without (PND) participated. They completed tests measuring free writing and vocabulary in English as a native (ED and END) and a foreign (PD and PND) language.

\section{RESULTS}

We found that both PD and PND knew fewer words of different difficulty, made more grammar errors, wrote shorter compositions, and composed shorter sentences than ED and END, demonstrating the influence of a NL and a negative linguistic transfer between synthetic Polish and analytical English. In a free writing task, tough, they committed an equal number of phonological and orthographic errors, probably choosing best-known words, which did not allow to demonstrate the expected deficits of students with dyslexia due to phonological deficit.

\section{CONCLUSIONS}

Generally, both PD and PND, despite having studied EFL for on average 7 years, failed to equal their ED and END peers' performance in a simple free writing task. Dyslexia and/or related spelling errors correlated with vocabulary in both Polish and English students, confirming that dyslexia may limit one's mental lexicon for both NL speakers and FL learners.

\section{KEY WORDS}

Polish; spelling; orthography

Organization - 1: Institute of Psychology, Faculty of Social Sciences, University of Gdansk, Poland · 2: Department of Psychology, Swansea University, United Kingdom

authors' Contributions - A: Study design - B: Data collection - C: Statistical analysis - D: Data interpretation .

E: Manuscript preparation · F: Literature search · G: Funds collection

Corresponding Author - Marta Łockiewicz, Ph.D., Institute of Psychology, Faculty of Social Sciences, University of Gdansk, 4 Bażyńskiego Str., 80-952 Gdansk, Poland, e-mail: psymlo@ug.edu.pl

TO CITE THIS ARTICLE - Łockiewicz, M., Jaskulska, M., \& Fawcett, A. (2019). The analysis of free writing, vocabulary, and dyslexia in English as a native and foreign language (English vs. Polish students). Health Psychology Report, 7(1), 57-68. https://doi.org/10.5114/hpr.2019.83385 


\section{BACKGROUND}

The ability to communicate one's beliefs and knowledge in both spoken (oracy) and written (literacy) form constitutes a prerequisite for an active citizenship. $E d-$ ucation and Training 2020 strategy (cf. Eurydice, 2005) encourages learners based in the European Union to learn 2 foreign languages (FL), in addition to their own native language (NL). Achieving proficiency in writing in a particular language might be especially challenging for students with dyslexia. In fact, they manifest difficulties in both their NL (ICD-10, 2000; Lyon, Shaywitz, \& Shaywitz, 2003) and EFL (English as a foreign language) in: spelling (Łockiewicz \& Jaskulska, 2016; Helland \& Kaasa, 2005; Lindgren \& Laine, 2011), free writing (Lindgren \& Laine, 2011) and morphology tasks (Helland \& Kaasa, 2005). These reports relate to the linguistic transfer of capabilities and deficits between NL (native language) and FL (foreign language) (Cummins, 1979; Sparks, Patton, Ganschow, Humbach, \& Javorsky, 2006).

Both long-term (Perfetti, 2007) and short-term (Nevo \& Breznitz, 2014; Rispens \& Baker, 2012) memory are needed for writing skills and FL learning (Woźnicki \& Zawadzka, 1981), though the significance of the former increases and the latter decreases when learning new FL words with the growing mental dictionary (Masoura \& Gathercole, 2005). However, lexicon access requires the involvement of short-term memory (Piskunowicz, Bieliński, Zgliński, \& Borkowska, 2013). In our studies, we concentrated on the free writing skills in EFL of Polish students with and without dyslexia.

Learning to spell requires phonological, morphological, and orthographic knowledge (Joshi, Treiman, Carreker, \& Moats, 2008/2009). Moreover, language structure impacts the writing acquisition, as it happens earlier in more transparent orthographies (Caravolas \& Volín, 2001). Polish orthography is more regular, consistent, and transparent as compared with the English one (Awramiuk, 2006). In Polish, major spelling difficulties include: 3 consonantal phonemes which have 2 corresponding graphemes (/3/ can be spelled as $\dot{\mathrm{z}}$ or $\mathrm{rz}, / \mathrm{x} /$ as $\mathrm{h}$ or $\mathrm{ch}, / \mathrm{u} /$ as ó or $\mathrm{u}$ ) and soft sounds (e.g. / 6 / as si or ś). Most phonemes, though, have only one corresponding grapheme (Gajda, 1999). In English, phonemes may be represented by different graphemes and/or their combinations in different words. These graphemes and/or their combinations may represent more than 1 phoneme, and additionally many exceptions occur (Nijakowska, 2010). Syntactically, though both languages follow subject-verb-object pattern, word order is more flexible in synthetic Polish than in analytical English, due to inflections: declension (of nouns, adjectives, pronouns, and numerals) and conjugation (of verbs), expressed morphologically through suffixes. In the previous core curriculum system that covered the years of our participants' early childhood education, Polish learners began to study English as FL at school entry, usually at the age of 6 (Ministry of National Education and Sport, 2002). The earliest instruction involves building oracy skills; later, reading, spelling, and writing (including text composition) are also taught, usually from 2 to 3 hours a week in elementary and junior high school.

The aim of our study was to compare free writing skills in Polish students with dyslexia (PD), Polish students without dyslexia (PND), English students with dyslexia (ED), and English students without dyslexia (END) in English as a native (ED and END) and a foreign language (PD and PND). As English and Polish have dissimilar orthographies in terms of grapheme-phoneme correspondence rules, we wanted to investigate if, given the choice which words to use, English and Polish students would differ while writing in English in the number of committed orthographic and phonological errors, as well as grammar, syntactic, and lexical ones, since Polish literature lists poor orthographic awareness and written expression, resulting in grammar and syntactic errors, as characteristic of dyslexia (Krasowicz-Kupis, 2008).

We assumed that the type and ratio of these errors would differ between Polish and English students, due to language characteristics. Moreover, we aimed to examine how the students' NL and FL mental lexicon access and phonological short-term memory, considering their diverse English language exposure, would relate to the correctness of their written works. The novelty of our approach lies in comparing the PD, PND, ED, and END's performance in working with the same testing material. We aimed to add evidence to the knowledge on the contribution of long-term and short-term memory to FL spelling and writing in different languages.

\section{PARTICIPANTS AND PROCEDURE}

\section{PARTICIPANTS}

Twenty-eight (46.67\%) English and 32 (53.33\%) Polish junior high school male students, who lived and studied in the United Kingdom and in Poland, respectively, participated in the study ${ }^{1}$. Within this group, $13(21.67 \%)$ of English students had dyslexia (English students with dyslexia: ED), 15 (25.00\%) did not (English students without dyslexia: END), 16 (26.67\%) of Polish students had dyslexia (Polish students with dyslexia: PD) and 16 (26.67\%) did not (Polish students without dyslexia: PND) participated in the study $\left(\chi^{2}(1)=0.08, p=.782\right)$. All the boys were either native speakers of English or Polish, respectively (not speaking English or Polish as NL was treated as an exclusion criterion), and were matched for gender, educa- 
tion, age $(M=14$ years, 2 months, $S D=13$ months for ED, $M=14$ years, 3 months, $S D=11$ months for END, $M=14$ years, 6 months, $S D=7$ months for PD, $M=14$ years, 5 months, $S D=8$ months for PND, $F(1,56)=0.09, p=.765$ ) and intelligence (as measured with The Standard Progressive Matrices: Raven 1991, 2006, for details please see Łockiewicz, Jaskulska, \& Fawcett, submitted, a) and years of learning English as a foreign language (EFL; only within the Polish group), both as an obligatory course at school $(M=7.18, S D=1.17$ years for $\mathrm{PD}, M=7.30, S D=0.48$ years for PND, $t(19)=0.30, p=.770)$, and as additional English private tutoring lessons $(M=2.58$, $S D=1.11$ years for $\mathrm{PD}, M=2.00, S D=0.00$ years for PND, $t(5)=0.48, p=.648)$. However, these latter lessons were taken by more Polish students with (5 boys $-18.75 \%)$ than without (1 boy $-3.00 \%)$ dyslexia $\left(\chi^{2}(1)=4.57, p=.033\right)$. The assignment to the criterion and the control group was carried out by a SENCO and a school psychologist, who co-ordinated the recruitment for the study in the United Kingdom and Poland, respectively. Each student in the criterion group had a dyslexia report, issued by a certified specialist. This prior assessment was confirmed by NL reading tasks. T-test for independent samples showed that ED scored lower in sight word efficiency $(M=75.23, S D=8.22$ for $\mathrm{ED}, M=87.50$, $S D=0.48$ for END, $t(25)=4.00, p \leq .001, d=1.60)$ and phonemic decoding efficiency $(M=40.92, S D=10.87$ for $\mathrm{ED}, M=54.36, S D=4.34$ for $\mathrm{END}, t(25)=4.92$, $p \leq .001, d=1.97)$. Similarly, PD read single words less accurately $(M=79.13, S D=4.92$, for PD, $M=85.50$, $S D=3.71$, for PND, $t(30)=4.14, p \leq .001, d=1.51)$ and more slowly $(M=85.33, S D=21.83$ for PD, $M=67.22, S D=13.56$ for PND, $t(30)=2.82, p=.008$, $d=0.83$ ) than PND (Real words reading task). Furthermore, PD read single nonwords less accurately $(M=41.13, S D=9.84$ for PD, $M=54.38, S D=12.30$ for PND, $t(30)=3.36, p=.002, d=1.23)$ and more slowly $(M=48.56, S D=9.65$ for $\mathrm{PD}, M=59.13, S D=11.92$ for PND, $t(30)=2.76, p=.010, d=1.01)$ than PND (Nonwords reading task).

\section{PROCEDURE}

All students and their parents expressed informed consent to participate prior to the study. Polish students also completed a short survey developed by the authors, which informed about EFL instruction and exposure. Each student took part in 2 stages of the assessment: a 45 min. group part (e. g. the Standard Progressive Matrices, English words in context, vocabulary, free writing), conducted by both Łockiewicz and Jaskulska, and a 30 min. individual part (e.g. reading measures, verbal and semantic fluency), half of which was conducted by Łockiewicz, and half by Jaskulska. All assessments were conducted at schools.

\section{METHODS}

Literacy measures in English

A free writing task. It assesses spelling and writing skills in English, as measured with the performance while composing a short text (by hand). The students had an A-4 piece of paper in front of themselves with a printed beginning: For the next holiday, I would like to go to... They were instructed to finish the sentence and elaborate on it - they were free to write anything they would find appropriate within a time limit of $5 \mathrm{~min}$ utes to complete the task. There was no additional time for preparation (e. g. brain-storming, planning, notetaking) due to the simplicity of the topic and a limited time. The students were expected to perform the task without stopping. After finishing the task, no revisions, editing, or self-corrections were possible. We assessed the following categories of errors: orthographic and phonological spelling errors, grammar (e.g. incorrect tense, inflectional ending, missing words), syntactic (incorrect word order), and lexical (e.g. incorrect word formation, collocation, faulty word translation) errors.

Vocabulary - by Nation $(2001 ; 1990)$. It assesses the receptive lexicon, of 1000 (39 questions with options: yes, no, I don't understand the question), of 2000 and of 3000 (a choice of a definition to three words from 6 options given, $\max =18$ points for each level) frequency. An average text consists in $84 \%$ of 3000 - frequency words (Nation, 2001).

Literacy measures in English to confirm the dyslexia diagnosis in the English group (they are used for comparison because of their potential contributions to the profile of dyslexia)

Sight Word Efficiency - by Torgesen, Wagner, and Rashotte (2012). It assesses the accuracy and fluency or decoding unrelated English words (as measured with the number of real words read within $45 \mathrm{sec}-$ onds), $\max =108$ points. A test-retest reliability coefficient (an average value for all 4 forms) was .91.

Phonemic Decoding Efficiency - by Torgesen, Wagner, and Rashotte (2012). It assesses the accuracy and fluency or decoding unrelated English nonwords (as measured with the number of nonwords read within 45 seconds), $\max =66$ points. A test-retest reliability coefficient (an average value for all 4 forms) was .90 .

Reading measures in Polish to confirm the dyslexia diagnosis in the Polish group (they are used for comparison because of their potential contributions to the profile of dyslexia)

Real words reading task - by Krasowicz-Kupis (Jaworowska, Matczak, \& Stańczak, 2010). It assesses the accuracy (as measured with the number of words read correctly) and fluency (as measured with the time of
Dyslexia and free writing in English as a native and a foreign language 
Marta Łockiewicz, Martyna Jaskulska, Angela Fawcett reading in seconds) of decoding 89 unrelated Polish real words ( $\max =89$ points). Syllables blending and self-corrections were treated as errors, following the test manual. A Cronbach's $\alpha$ for accuracy was .96.

Nonwords reading task - by Bogdanowicz (Jaworowska et al., 2010). It assesses the accuracy (as measured with the number of errors) and fluency (as measured with the number of nonwords read within 1 minute) of decoding 71 unrelated Polish nonwords ( $\max =71$ points). Syllables blending and self-corrections were not treated as errors, following the test manual. A Pearson's $r$ coefficient for test-retest reliability was .93 .

\section{Cognitive functions}

Verbal fluency - by Fawcett and Nicolson (2005), as measured with the number of words beginning with $\mathrm{S}$ that are listed within a minute. This letter is also commonly used in Polish studies (Stolarska, Kroczka, Gergont, Steczkowska, \& Kaciński, 2008).

Semantic fluency - by Fawcett and Nicolson (2005), as measured with the number of animals that are listed within a minute.

Nonword repetition

a) The English group: by Fawcett, an experimental task prepared for this study. It assessed phonological short-term memory, as measured with the number of repeated nonwords, given in series consisting of 3 to 6 nonwords ( $\max =18$ points, sample item: stettle).

b) The Polish group: by Bogdanowicz, Kalka, Karpińska, Sajewicz-Radtke, and Radtke (2012), as measured with the number of repeated nonwords, given in series consisting of 3 to 6 nonwords $(\max =18$ points, sample item: $z o r a)$.

\section{RESULTS}

\section{FREE WRITING SKILLS - ORTHOGRAPHIC, PHONOLOGICAL, AND GRAMMAR ERRORS}

In a free writing task, the ANOVA test 2x2 (dyslexia $\mathrm{x}$ NL) and Tukey post hoc tests (Table 1) showed no main effect for dyslexia and for NL for orthographic errors. No main effect for dyslexia and for NL was also observed for phonological errors (orthographic errors: $M=3.25, S D=2.55, \min =1.00, \max =8.00$ for $\mathrm{ED}, M=2.11, S D=1.76, \min =1.00, \max =6.00$ for END, $M=1.90, S D=1.60, \min =1.00, \max =6.00$ for PD, $M=2.33, S D=1.75, \min =1.00, \max =5.00$ for PND; phonological errors: $M=1.57, S D=1.13$, $\min =1.00, \max =4.00$ for $\mathrm{ED}, M=1.00, S D=0.00$, $\min =1.00, \max =1.00$ for $\mathrm{END}, M=1.50, S D=1.22$, $\min =1.00, \max =4.00$ for $\mathrm{PD}, M=1.33, S D=0.58$, $\min =1.00, \max =2.00$ for PND).

Moreover, the $t$-test with repeated measures showed that PD $(t(15)=1.37, p=.190, d=0.36)$ and
PND $(t(15)=1.46, p=.164, d=0.44)$ did not differ in the number of phonological and orthographic errors they made. Conversely, $\mathrm{ED}(t(12)=2.09, p=.059$, $d=0.70$, statistical trend) and $\operatorname{END}(t(14)=2.02$, $p=.063, d=0.72$, statistical trend) made more orthographic than phonological errors.

In a free writing task, the ANOVA test $2 \times 2$ (dyslexia $\mathrm{x}$ NL) and Tukey post hoc (Table 1) tests showed that Polish students made more grammar errors as compared with their English peers (main effect for $\mathrm{NL})$. Specifically, $\mathrm{PD}(M=4.92, S D=2.29, \min =2.00$, $\max =10.00)$ made more errors than $\mathrm{ED}(M=1.80$, $S D=1.03, \min =1.00, \max =4.00)$, and $\operatorname{PND}(M=5.08$, $S D=2.22, \min =1.00, \max =9.00)$ made more er rors that both $\operatorname{END}(M=2.00, S D=1.00, \min =1.00$, $\max =3.00$, statistical trend) and ED. However, PD performed on a level with END. No other significant differences were observed. No means comparison was calculated for lexical and syntactic errors, as few English students made these at all. In fact, only $2(15 \%)$ ED and $1(7 \%)$ END made lexical errors, and $2(15 \%)$ ED and no END made syntactic errors.

\section{FREE WRITING SKILLS - COMPOSITION CREATING SKILLS}

The ANOVA test 2x2 (dyslexia x NL) and Tukey post hoc tests (Table 2) indicated that Polish students wrote shorter compositions than their English peers (main effect for NL). Specifically, PD $(M=37.85, S D=19.99$, $\min =14.00, \max =90.00)$ created shorter compositions than END $(M=73.80, S D=21.34, \min =45.00$, $\max =132.00)$ and $\operatorname{ED}(M=73.62, S D=17.75$, $\min =36.00, \max =103.00) . \operatorname{PND}(M=41.19$, $S D=22.46, \min =8.00, \max =77.00)$ created shorter compositions than END and ED. Moreover, 3 (18.75\%) PD did not attempt the task at all. The students, however, did not differ in the number of sentences included $(M=4.31, S D=1.94, \min =2.00, \max =9.00$ for $\mathrm{PD}, M=5.19, S D=2.23, \min =2.00, \max =8.00$ for PND, $M=4.54, S D=0.97, \min =3.00, \max =6.00$ for $\mathrm{ED}, M=4.33, S D=1.59, \min =2.00, \max =7.00$ for END, no main effect for NL). This is because the sentences written by the English participants were longer $(M=8.92, S D=2.60, \min =4.00, \max =12.00$ for $\mathrm{PD}, M=7.69, S D=2.55, \min =4.00, \max =13.00$ for PND, $M=16.85, S D=4.22, \min =9.00, \max =26.00$ for $\mathrm{ED}, M=18.47, S D=5.22, \min =9.00, \max =32.00$ for END, main effect for NL). PD's sentences were shorter than both ED's, and END's ones, and PND's texts were shorter than both ED's, and END's ones. In the Polish and English group, the number of used words correlated positively with the number of used sentences ( $r=.60$ and $r=.84$, respectively).

In their essays, ED used 957 words. Among these, 10 most frequent were: $I$ (56 uses $-5.9 \%$ of all words), to (45-4.7\%), the (38 - 4\%), and (25-2.6\%), 


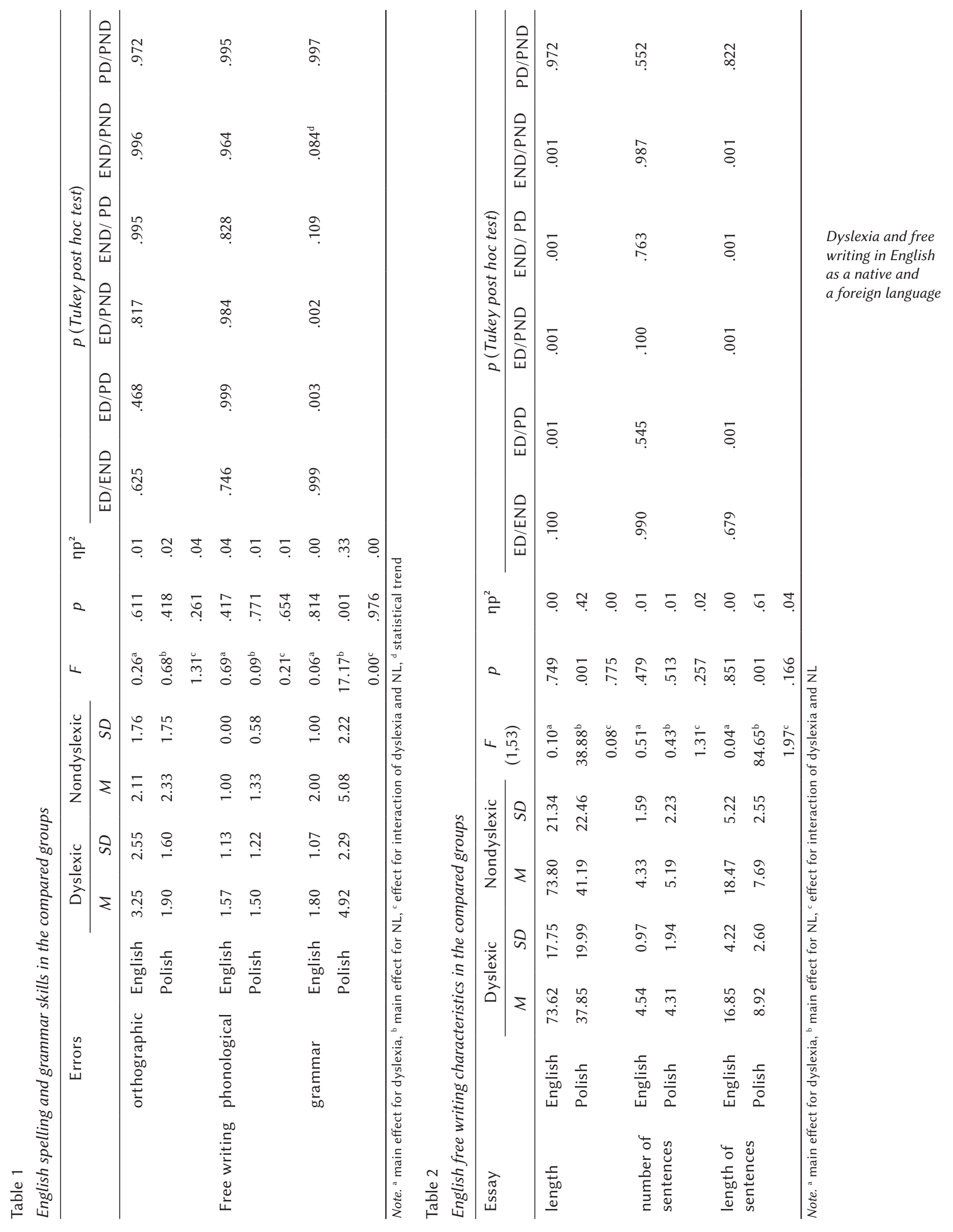


Marta Łockiewicz, Martyna Jaskulska, Angela Fawcett a $(25-2.6 \%)$, would $(22-2.3 \%)$, because $(21-2.2 \%)$, it $(19-2 \%)$, go $(19-2 \%)$, there $(19-2 \%)$. The longest word used was mountaineering (14 letters). 46\% (439) words had only 3 or fewer letters.

In their essays, END used 1107 words. Among these, 10 most frequent were: to (68 uses $-6.1 \%$ of all words), I(65-5.9\%), the (42-3.8\%), would (34-3.1\%), and $(33-3 \%)$, there $(25-2.3 \%)$, like $(25-2.3 \%)$, go $(24-2.2 \%)$, is $(21-1.9 \%)$, in $(19-1.7 \%)$. The longest word used was investigations (14 letters).

In their essays, PD used 493 words. Among these, 10 most frequent were: $I$ (33 uses $-6.7 \%$ of all words), and (23 - 4.7\%), to $(21-4.3 \%)$, in $(16-3.2 \%)$, $a(14-2.8 \%)$, the $(13-2.6 \%)$, my $(12-2.4 \%)$, go $(11-2.2 \%)$, like $(8-1.6 \%)$, is $(7-1.4 \%)$. The longest words used were grandmother and grandfather (11 letters each).

In their essays, PND used 659 words. Among these, 10 most frequent were: $I$ (55 uses $-8.3 \%$ of all words), to (33-5\%), go (29-4.4\%), and (28-4.2\%), my $(22-3.3 \%)$, in $(21-3.2 \%)$, the $(15-2.3 \%)$, is $(14-2.1 \%)$, like $(13-2 \%)$, there $(11-1.7 \%)$. The longest words used were grandparents and disadvantage (12 letters).

\section{VOCABULARY}

The ANOVA test 2x2 (dyslexia $\mathrm{x}$ NL) and Tukey post hoc tests (Table 3) showed that English students knew English vocabulary better than Polish students (main effect for NL for 1000, 2000, and 3000 word frequency). No main effect for dyslexia was observed. Specifically, ED did not differ from END in their lexicon size for the $1000(M=36.15, S D=1.91, \min =33.00, \max =39.00$ for $\mathrm{ED}, M=38.00, S D=1.20, \min =36.00, \max =39.00$ for END), $2000(M=16.85, S D=1.14, \min =14.00$, $\max =18.00$ for $\mathrm{ED}, M=17.40, S D=1.55, \min =12.00$, $\max =18.00$ for $\mathrm{END})$ and $3000(M=17.23, S D=0.83$, $\min =15.00, \max =18.00$ for $\mathrm{ED}, M=17.93, S D=0.26$, $\min =17.00, \max =18.00$ for END) frequency level. Similarly, PD did not differ from PND in their lexicon size for the $1000(M=29.56, S D=4.47, \min =23.00$, $\max =36.00$ for $\mathrm{PD}, M=27.88, S D=6.11, \min =18.00$, $\max =37.00$ for PND), $2000(M=8.56, S D=2.92$, $\min =2.00, \max =13.00$ for $\mathrm{PD}, M=9.56, S D=3.67$, $\min =4.00, \max =16.00$ for $\mathrm{PND})$ and $3000(M=9.50$, $S D=3.69, \min =3.00, \max =17.00$ for $\mathrm{PD}, M=9.31$, $S D=3.89, \min =2.00, \max =16.00$ for PND) frequency level. However, PD and PND knew fewer words than both ED and END at all levels of frequency.

\section{VERBAL, SEMANTIC, AND PHONOLOGICAL MEMORY}

The ANOVA test 2x2 (dyslexia x NL) and Tukey post hoc tests (Table 3) showed that ED, END, PD, PND did not differ in their phonological short-term mem- ory and semantic fluency. There was, however, a statistically significant interaction between the effects of dyslexia and NL on verbal fluency. PD $(M=9.69$, $S D=4.73, \min =3.00, \max =20.00)$ produced fewer words starting with $S$ than $\mathrm{ED}(M=16.92, S D=4.05$, $\min =8.00, \max =23.00)$ and $\operatorname{END}(M=15.07$, $S D=4.08, \min =8.00, \max =22.00)$. PND $(M=13.06$, $S D=4.27, \min =5.00, \max =18.00)$ produced fewer words than ED and performed on a level with END.

\section{CORRELATIONS BETWEEN MEMORY AND WRITING}

To investigate the relationship between dyslexia, English mental lexicon, verbal and semantic fluency, phonological short-term memory and the number of orthographic, phonological, and grammar errors, we calculated Pearson product-moment correlations. In the Polish group, the results (Table 4) suggest a moderate positive correlation between dyslexia and verbal fluency (dyslexic students listed fewer words beginning with s) in the Polish group. Semantic fluency correlated negatively with grammar errors (a moderate correlation).

In the English group, the results (Table 5) suggest a large positive correlation between dyslexia and 1000 and 3000 frequency vocabulary (dyslexic students knew fewer words).

\section{DISCUSSION}

We found that in a free writing task ED, END, PD, PND made an equal number of phonological and orthographic errors. As this was a short and relatively easy task, students likely chose to use words which were well-known to them, probably the simplest ones. This is supported by the finding in our earlier study with the same groups (Eockiewicz, Jaskulska, \& Fawcett, submitted, b), where students had to spell to dictation a list of selected words, with no choice of their own, covering possible areas of difficulty for learners with dyslexia. In this particular task, PD made more phonological and orthographic errors than ED and END, PND made more orthographic errors than ED and END, only PND performed on a level with ED. EFL spelling deficits in dyslexia has been reported in several languages (Bonifacci, Canducci, Gravagna, \& Palladino, 2017; van Sette et al., 2017), including Polish (Łockiewicz \& Jaskulska, 2016). In the present study, however, ED and END, made more orthographic than phonological errors (statistical trend), which is in accordance with the proportion of errors we observed in a single word spelling task in a related study with the same group (Łockiewicz et al., submitted, b), and is concordant with reports that when learning to spell, learners advance from 


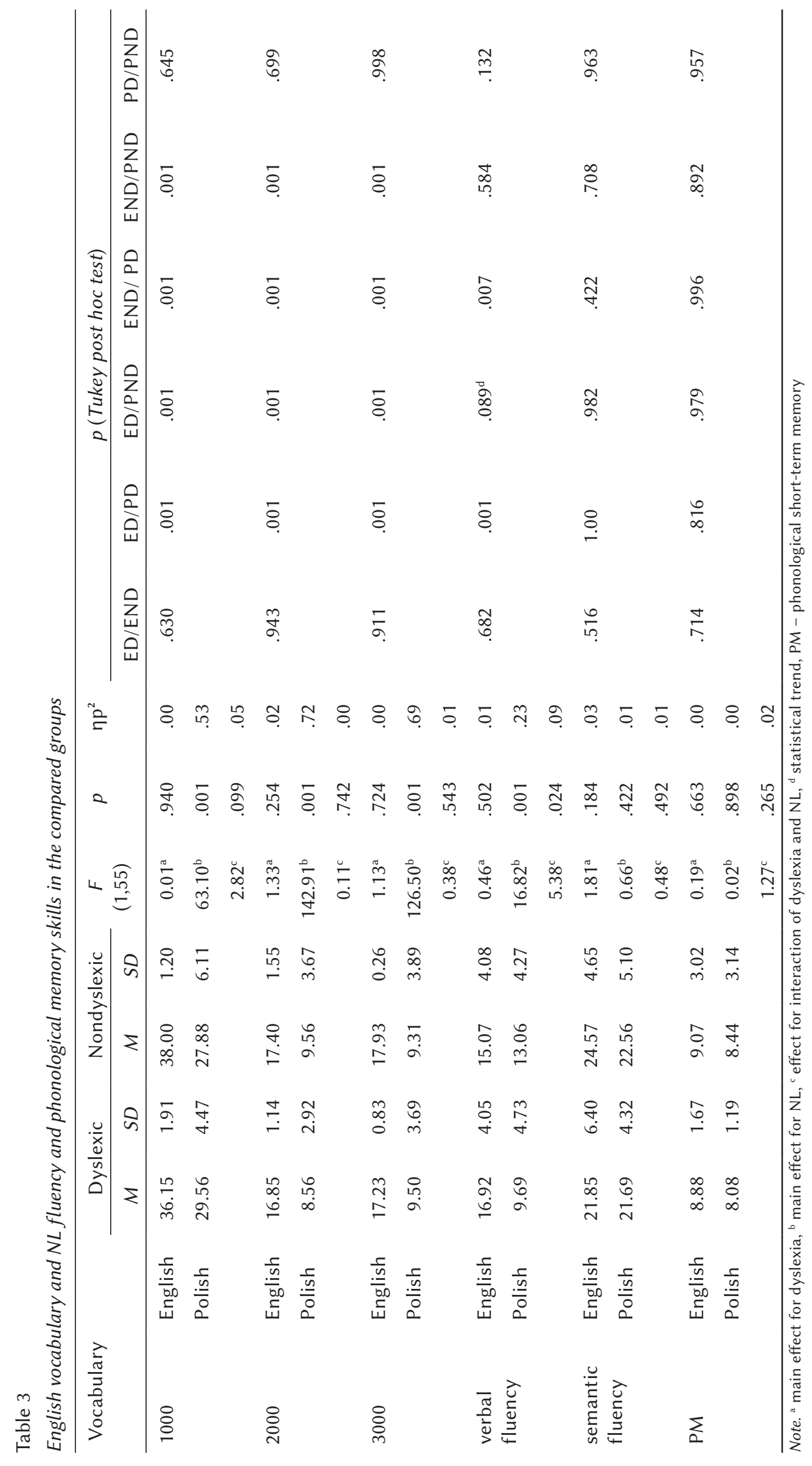

Dyslexia and free writing in English as a native and a foreign language 
Table 4

Correlations between the study variables - the Polish group

Marta Łockiewicz,

Martyna

Jaskulska, Angela Fawcett

\begin{tabular}{|c|c|c|c|c|c|c|c|c|c|c|}
\hline & & 2. & 3. & 4. & 5. & 6. & 7. & 8. & 9. & 10. \\
\hline 1. & Dyslexia $^{a, d}$ & -.16 & .15 & -.03 & $.36^{*}$ & .10 & -.09 & .13 & -.08 & .04 \\
\hline 2. & $\begin{array}{l}\text { Vocabulary } \\
1000 \text { frequency }\end{array}$ & & $.61^{* *}$ & $.59^{* *}$ & -.10 & .20 & .20 & .11 & -.46 & .17 \\
\hline 3. & $\begin{array}{l}\text { Vocabulary } \\
2000 \text { frequency }\end{array}$ & & & $.44^{*}$ & -.08 & .27 & .20 & .03 & -.15 & .15 \\
\hline 4. & $\begin{array}{l}\text { Vocabulary } \\
3000 \text { frequency }\end{array}$ & & & & -.16 & .08 & .16 & .00 & .19 & -.01 \\
\hline 5. & Verbal fluency & & & & & .20 & .03 & .44 & -.10 & .26 \\
\hline 6. & Semantic fluency & & & & & & -.26 & -.11 & .18 & $.40^{*}$ \\
\hline 7. & $\begin{array}{l}\text { Phonological } \\
\text { memory }\end{array}$ & & & & & & & -.04 & -.24 & -.09 \\
\hline 8. & $\begin{array}{l}\text { Orthographic } \\
\text { errors }^{\text {b }}\end{array}$ & & & & & & & & .63 & .15 \\
\hline 9. & $\begin{array}{l}\text { Phonological } \\
\text { errors }^{\text {b }}\end{array}$ & & & & & & & & & -.44 \\
\hline 10. & Grammar ${ }^{b}$ & & & & & & & & & \\
\hline
\end{tabular}

Note. ${ }^{*} p \leq .05,{ }^{* *} p \leq .01$; Pearson product-moment correlations, except: ${ }^{\mathrm{d}}$ point-biserial correlation coefficients;

${ }^{\mathrm{a}} 1$ - dyslexia, 2 - control, ${ }^{\mathrm{b}}$ higher score signifies worse performance

Table 5

Correlations between the study variables - the English group

\begin{tabular}{|c|c|c|c|c|c|c|c|c|c|c|}
\hline & & 2. & 3. & 4. & 5. & 6. & 7. & 8. & 9. & 10. \\
\hline 1. & Dyslexia $^{\mathrm{a}, \mathrm{d}}$ & $.52^{* *}$ & .20 & $.52^{* *}$ & -.23 & .25 & .22 & -.27 & -.33 & .09 \\
\hline 2. & $\begin{array}{l}\text { Vocabulary } \\
1000 \text { frequency }\end{array}$ & & -.19 & .05 & -.16 & .00 & .04 & .09 & .10 & .06 \\
\hline 3. & $\begin{array}{l}\text { Vocabulary } \\
2000 \text { frequency }\end{array}$ & & & .26 & -.17 & .31 & .29 & -.09 & -.09 & -.35 \\
\hline 4. & $\begin{array}{l}\text { Vocabulary } \\
3000 \text { frequency }\end{array}$ & & & & -.18 & .08 & .20 & -.11 & -.42 & -.04 \\
\hline 5. & Verbal fluency & & & & & .16 & .20 & -.17 & .03 & .03 \\
\hline 6. & Semantic fluency & & & & & & .06 & -.14 & .03 & .16 \\
\hline 7. & $\begin{array}{l}\text { Phonological } \\
\text { memory }\end{array}$ & & & & & & & -.22 & -.05 & .04 \\
\hline 8. & Orthographic & & & & & & & & .50 & -.11 \\
\hline 9. & Phonological $^{\mathrm{b}}$ & & & & & & & & & .26 \\
\hline 10. & Grammar ${ }^{b}$ & & & & & & & & & \\
\hline
\end{tabular}

Note. ${ }^{*} p \leq .05,{ }^{* *} p \leq .01 ;{ }^{\mathrm{d}}$ statistical trend; Pearson product-moment correlations, except: ${ }^{\mathrm{d}}$ point-biserial correlation coefficients; ${ }^{\mathrm{a}} 1$ - dyslexia, 2 - control, ${ }^{\mathrm{b}}$ higher score signifies worse performance

using a phonological to an orthographical strategy (Zhao, Quiroz, Dixon, \& Joshi, 2016).

We also found that Polish students made more grammar errors as compared with their English peers, showing the impact of a NL. Specifically, PD made more such errors than ED, and PND more errors that both END (statistical trend) and ED. However, PD performed on a level with END. FL grammar errors can result from a negative linguistic transfer due to language interference (Benson, 2002; Zybert, 1999), 
especially as inflection plays a much more significant role in indicating the function of a word in Polish than it does in English, hence the problems with word order, rules of concord, and articles usage. This difference was visible even though Polish students likely attempted to use the simplest grammar structures, as their sentences were shorter than those written by the English peers.

In our study, PD and PND wrote shorter compositions than both END and ED, showing the effect of NL; $3(18.75 \%)$ PD did not attempt the task at all. Similarly, in an older group than our participants, Polish university students with dyslexia wrote equally long essays in their NL (measured with both the number of words and the number of sentences) as compared with their nondyslexic peers (Bogdanowicz, Łockiewicz, Bogdanowicz, \& Pachalska, 2014). No relationship between dyslexia and the length of the composition is in accordance with Berninger et al. study (2008), which found that handwriting did not predict the dyslexic children's written expression, including word fluency. However, there are reports that learners with dyslexia are poor in handwriting fluency (Connelly, Campbell, MacLean, \& Barnes, 2006; Hatcher, Snowling, \& Griffiths, 2002). However, Sumner, Connelly, and Barnett (2013) argue that producing fewer word within a time limit is not due to actual slower speed of handwriting in dyslexia, but to making more freqent and longer pauses when composing a text, which is linked to spelling skills. Thus, this issue requires further study. In our study, the 4 groups did not differ in the number of sentences, and used mostly short, monosyllabic words, which are frequent in English (Miestamo, Sinnemäki, \& Karlsson, 2008). Among the 10 most frequent words 50\% were common for all groups: I, to, the, and, go, reflecting the nature of English.

We found that both PD and PND knew fewer English words than ED and END at all assessed levels of frequency: 1000, 2000, and 3000. Within the same NL groups, PD and ED did not differ from PND and END, respectively, in their lexicon sizes. Thus, the vocabulary knowledge depended only on the country, not on dyslexia. This result is consistent with an earlier study of Polish junior high school students with dyslexia who displayed the same lexicon sizes when compared in 1000 and 2000 - frequency vocabulary (Łockiewicz \& Jaskulska, 2015). The discrepancy between the word knowledge between Polish and English learners is conspicuous, despite the fact that $95 \%$ elementary school EFL teachers in Poland declare teaching vocabulary during every lesson (Muszyński, Campfield, \& Szpotowicz, 2015). Still, Polish students failed to learn even the easiest, 1000-frequency vocabulary on a level comparable to their English peers. This result could be explained by inefficient EFL exposure, limited usually only to a few EFL classes at school, which are typically conducted partially in Polish (GajewskaDyszkiewicz et al., 2011).
In our study, ED, END, PD, PND did not differ in their phonological short-term memory and semantic fluency, which was an expected result, as these tasks were conducted in their respective NL. However, unexpectedly, PD produced fewer words starting with the letter $s$ than ED and END, and PND fewer words than ED (statistical trend), which demonstrated an interaction between the effects of dyslexia and NL. Similarly, Polish junior high school students with and without dyslexia also performed on a level in a phonological short-term memory task and semantic fluency in an earlier study (Łockiewicz \& Jaskulska, 2015), though verbal short-term memory deficits are reported as characteristic of dyslexia (Hoien, Lundberg, Stanovich, \& Bjaalid, 1995). Literature reports on dyslexic students' performance in verbal fluency have been inconclusive, indicating deficits (Reiter, Tucha, \& Lange, 2005), average performance (Reid, Szczerbinski, Iskierka-Kasperek, \& Hansen, 2007), or only phonological fluency deficits (Lipowska, Bogdanowicz, \& Buliński, 2008). As Polish orthography is more transparent than the English one, Polish learners process bigger orthographic chunks as compared to the English ones (Krasowicz-Kupis, 2008). In Polish, most graphemes have only one corresponding phoneme (Gajda, 1999). However, the letter s can be used in different environment, influencing its pronunciation: /s/ in sok (juice), / $/$ / as in szafa (wardrobe), or /6/ as in siano (hay). These options could have caused confusion for both dyslexic and nondyslexic learners, which could explain the unexpected inferior performance when compared with their English peers. This was confirmed by the fact that only in the Polish group dyslexia correlated moderately and negatively with verbal fluency. As the performance in this task relied on the retrieval of phonological information from the mental dictionary (Jones, Branigan, \& Kelly, 2009), it may be impaired in case of phonological deficits, even when they accompany rich vocabulary (Hatcher \& Snowling, 2008).

In our study, in the Polish group, orthographic errors correlated moderately with dyslexia, and phonological errors largely with 1000, 2000, and 3000 frequency vocabulary, and moderately with phonological short-term memory. The development of verbal short-term memory relates to higher accuracy of language tasks (Brady, 1986). Moreover, it seems that when students did not know the required word by heart, they attempted to spell it using phonological rules of English. As this knowledge was limited, they committed phonological errors. The relation between orthographic errors and dyslexia was expected, taking into account the symptomatology of dyslexia (Lyon et al., 2003), and Linguistic Coding Differences Hypothesis (Sparks et al., 2006). Moreover, we found that semantic fluency correlated positively and moderately with grammar errors. Students could have relied on retrieving the whole words with
Dyslexia and free writing in English as a native and a foreign language 
Marta Łockiewicz, Martyna Jaskulska, Angela Fawcett grammatical endings from mental lexicons, rather than applying grammar rules, which could have diminished their correctness.

In our study, in the English group, dyslexia correlated largely and negatively with 1000 and 3000 frequency vocabulary. Since mental dictionary skills involve retrieval of phonological and orthographic information from the long-term memory (Frith, Lander, \& Frith, 1995), which might include impaired phonological representations of lexical items in case of dyslexia (Elbro \& Jensen, 2005; Goswami, Ziegler, \& Richardson, 2005), and NL phonological skills often relate with limited reading experience (Sparks, Patton, Ganschow, \& Humbach, 2012), it may influence learners' limited vocabulary, as reading exposure allows one to encounter new words in context (Anderson, Fielding, \& Wilson, 1986).

The major limitation of our study was a small number of participants and the fact that all of them were male. In future studies, we would like to include a task in which different aspects of grammar would be examined, to analyse a possible pattern of difficulties in works of PD and PND learners as compared with ED and END.

\section{CONCLUSIONS}

We found that both PD and PND knew fewer words of different difficulty, made more grammar errors, wrote shorter compositions, and composed shorter sentences than ED and END, demonstrating the influence of a NL and a negative linguistic transfer between synthetic Polish and analytical English. In a free writing task, tough, they committed an equal number of phonological and orthographic errors, probably choosing best-known words, which did not allow to demonstrate the expected deficits of students with dyslexia due to phonological deficit. Generally, both PD and PND, despite having studied EFL for on average 7 years, failed to equal their ED and END peers' performance in a simple free writing task. Dyslexia and/or related spelling errors correlated with vocabulary in both Polish and English students, confirming that dyslexia may limit one's mental lexicon for both NL speakers and FL learners.

\section{ACKNOWLEDGMENTS}

The research was funded by National Science Centre, Poland (grant no. 2014/14/M/HS6/00922).

\section{ENDNOTE}

1 The same group participated in a study by Łockiewicz, Jaskulska, \& Fawcett (submitted, a) and Łockiewicz, Jaskulska, \& Fawcett (submitted, b).

\section{References}

Anderson, R. C., Fielding, L., \& Wilson, P. T. (1986). Growth in reading and how children spend their time outside of school. Champaign, IL; Cambridge, MA: University of Illinois at Urbana-Champaign; Bolt Beranek and Newman Inc.

Awramiuk, E. (2006). Lingwistyczne podstawy początkowej nauki czytania i pisania po polsku [Linguistic bases for the initial learning of reading and writing in Polish]. Białystok: Transhumana.

Benson, C. (2002). Key concepts in ELT. Transfer/ cross-linguistic influence. ELT Journal, 56, 68-70. https://doi.org/10.1093/elt/56.1.68

Berninger, V. W., Nielsen, K. H., Abbott, R. D., Wijsman, E., \& Raskind, W. (2008). Writing problems in developmental dyslexia: under-recognized and under-treated. Journal of School Psychology, 46, 1-21. https://doi.org/10.1016/j.jsp.2006.11.008

Bogdanowicz, M., Kalka, D., Karpińska, E., SajewiczRadtke, U., \& Radtke, B. M. (2012). Bateria metod diagnozy przyczyn niepowodzeń szkolnych u uczniów gimnazjów. Bateria GIM [The battery of methods diagnosing reasons for school failures in junior high school students. GIM battery]. Gdańsk: Pracownia Testów Psychologicznych i Pedagogicznych SEBG.

Bogdanowicz, K. M., Łockiewicz, M., Bogdanowicz, M., \& Pachalska, M. (2014). Characteristics of cognitive deficits and writing skills of Polish adults with developmental dyslexia. International Journal of Psychophysiology, 93, 78-83. https://doi.org/10.1016/j. ijpsycho.2013.03.005

Bonifacci, P., Canducci, E., Gravagna, G., \& Palladino, P. (2017). English as a foreign language in bilingual language-minority children, children with dyslexia and monolingual typical readers. Dyslexia, 23, 181-206. https://doi.org/10.1002/dys.1553

Brady, S. (1986). Short-term memory, phonological processing, and reading ability. Annals of Dyslexia, 36, 138-153. https://doi.org/10.1007/BF02648026

Caravolas, M., \& Volín, J. (2001). Phonological spelling errors among dyslexic children learning a transparent orthography: the case of Czech. Dyslexia, 7, 229-245. https://doi.org/10.1002/dys.206

Connelly, V., Campbell, S., MacLean, M., \& Barnes, J. (2006). Contribution of lower order skills to the written composition of college students with and without dyslexia. Developmental Neuropsychology, 29, 175-196.

Cummins, J. (1979). Linguistic interdependence and the educational development of bilingual children. Review of Educational Research, 49, 222-251. https://doi.org/10.2307/1169960

Elbro, C., \& Jensen, M. N. (2005). Quality of phonological representations, verbal learning, and phoneme awareness in dyslexic and normal readers. Scandinavian Journal of Psychology, 46, 375-384. 
Eurydice (2005). Key data on teaching languages at school in Europe, 2005 Ediction. Raport Eurydice. Brussels: Eurydice European Unit.

Fawcett, A. J., \& Nicolson, R. I. (2005). The Dyslexia Screening Test - Secondary. DST-S. London: Harcourt Assessment.

Frith, U., Lander, K., \& Frith, C. (1995). Dyslexia and verbal fluency: more evidence for a phonological deficit. Dyslexia, 1, 2-11.

Gajda, S. (1999). O językowym planie wyrażania, czyli o... [On linguistic plan of expressing, that is on...]. In T. Gałkowski \& G. Jastrzębowska (Eds.), Logopedia - pytania i odpowiedzi [Speech therapy - questions and answers] (pp. 27-36). Opole: Wydawnictwo Uniwersytetu Opolskiego.

Gajewska-Dyszkiewicz, A., Grudniewska, M., KuIon, F., Kutyłowska, K., Paczuska, K., Rycielska, L., \& Szpotowicz, M. (2011). Europejskie Badanie Kompetencji Językowych ESLC. Raport krajowy [European Screening for Language Competences. State report]. Warszawa: Instytut Badań Edukacyjnych.

Goswami, U., Ziegler, J. C., \& Richardson, U. (2005). The effects of spelling consistency on phonological awareness: a comparison of English and German. Journal of Experimental Child Psychology, 92, 345-365. https://doi.org/10.1016/j.jecp.2005.06.002

Hatcher, J., \& Snowling, M. J. (2008). Hipoteza reprezentacji fonologicznych jako sposób rozumienia dysleksji: od teorii do praktyki [The phonological representations hypothesis of dyslexia: from theory to practice]. In G. Reid \& J. Wearmouth (Eds.), Dysleksja. Teoria i praktyka [Dyslexia. Theory and practice] (pp. 103-120). Gdańsk: Gdańskie Wydawnictwo Psychologiczne.

Hatcher, J., Snowling, M. J., \& Griffiths, Y. M. (2002). Cognitive assessment of dyslexic students in higher education. The British Journal Of Educational Psychology, 72, 119-133.

Helland, T., \& Kaasa, R. (2005). Dyslexia in English as a second language. Dyslexia, 11, 41-60. https://doi. org/10.1002/dys.286

Hoien, T., Lundberg, I., Stanovich, K. E., \& Bjaalid, I. K. (1995). Components of phonological awareness. Reading and Writing, 7, 171-188. https://doi. org/10.1007/bf01027184

ICD-10. (2000). Międzynarodowa Statystyczna Klasyfikacja Chorób i Problemów Zdrowotnych. Rewizja dziesiąta. Klasyfikacja zaburzeń psychicznych i zaburzeń zachowania w ICD-10. Opisy kliniczne i wskazówki diagnostyczne [International Statistical Classification of Diseases and Related Health Problems. Tenth Revision. Classification of mental and behavioural disorders in ICD-10. Clinical findings and diagnostic cues]. Kraków-Warszawa: Vesalius.

Jaworowska, A., Matczak, A., \& Stańczak, J. (2010). Diagnoza dysleksji. Aneks do przewodnika diagnostycznego. Normalizacja dla uczniów klasy V szkoty podstawowej [Dyslexia diagnosis. Annex to the diagnostic manual. Normalisation for the primary school studnents, year 5]. Warszawa: Pracownia Testów Psychologicznych Polskiego Towarzystwa Psychologicznego.

Jones, M. W., Branigan, H. P., \& Kelly, M. L. (2009). Dyslexic and nondyslexic reading fluency: rapid automatized naming and the importance of continuous lists. Psychonomic Bulletin \& Review, 16, 567-572. https://doi.org/10.3758/PBR.16.3.567

Joshi, R. M., Treiman, R., Carreker, S., \& Moats, L. C. (2008/2009). How words cast their spell: spelling instruction focused on language, not memory, improves reading and writing. American Educator, 32, 6-16, 42-43.

Krasowicz-Kupis, G. (2008). Psychologia dysleksji [The psychology of dyslexia]. Warszawa: Wydawnictwo Naukowe PWN.

Lindgren, S. A., \& Laine, M. (2011). Multilingual dyslexia in university students: reading and writing patterns in three languages. Clinical Linguistics \& Phonetics, 25, 753-766. https://doi.org/10.3109/ 02699206.2011 .562594

Lipowska, M., Bogdanowicz, M., \& Buliński, L. (2008). Language skills in children with ADHD and developmental dyslexia. Acta Neuropsychologica, 6, 369-379.

Lyon, G. R., Shaywitz, S. E., \& Shaywitz, B. A. (2003). A definition of dyslexia. Defining dyslexia, comorbidity, teachers' knowledge of language and reading. Annals of Dyslexia, 53, 1-14.

Łockiewicz, M., \& Jaskulska, M. (2015). Mental lexicon, working memory, and L2 (English) vocabulary in Polish students with and without dyslexia. CEPS Journal, 5, 71-90.

Łockiewicz, M., \& Jaskulska, M. (2016). Difficulties of Polish students with dyslexia in reading and spelling in English as L2. Learning and Individual Differences, 51, 256-264. https://doi.org/10.1016/j. lindif.2016.08.037

Łockiewicz, M., Jaskulska, M., \& Fawcett, A. J. (submitted, a). Decoding and word recognition in English as a native and a foreign language in students with and without dyslexia.

Łockiewicz, M., Jaskulska, M., \& Fawcett, A. J. (submitted, b). Single word spelling in English as a native and a foreign language in students with and without dyslexia.

Masoura, E. V., \& Gathercole, S. E. (2005). Contrasting contributions of phonological short-term memory and long-term knowledge to vocabulary learning in a foreign language. Memory, 13, 422429. https://doi.org/10.1080/09658210344000323

Miestamo, M., Sinnemäki, K., \& Karlsson, F. (Eds.) (2008). Language complexity: typology, contact, change. Amsterdam: John Benjamins Publishing Company.

Ministry of National Education and Sport (2002). Rozporzadzenie Ministra Edukacji Narodowej i Sportu
Dyslexia and free writing in English as a native and a foreign language 
Marta Łockiewicz, Martyna Jaskulska, Angela Fawcett z dnia 12 lutego 2002 r. w sprawie ramowych planów nauczania w szkołach publicznych [Regulation of Minister of National Education and Sport of February 12, 2002 on the framework curricula in public schools] (Dz. U. z 2002 r., Nr 15, poz. 142). Warszawa: Kancelaria Prezesa Rady Ministrów.

Muszyński, M., Campfield, D., \& Szpotowicz, M. (2015). Jezzyk angielski w szkole podstawowej - proces $i$ efekty nauczania [English in primary school - the process and effects of teaching]. Warszawa: Instytut Badań Edukacyjnych.

Nation, P. (2001). Learning vocabulary in another language. Cambridge: Cambridge University Press.

Nation, P. (2001; 1990). Frequency based tests: Recognition. Retrieved from https://www.lextutor.ca/tests

Nevo, E., \& Breznitz, Z. (2014). Effects of working memory and reading acceleration training on improving working memory abilities and reading skills among third graders. Child Neuropsychology, 20, 752-765. https://doi.org/10.1080/09297049.2013.863272

Nijakowska, J. (2010). Dyslexia in the foreign language classroom. Bristol: St. Nicholas House.

Perfetti, C. (2007). Reading ability: lexical quality to comprehension. Scientific Studies of Reading, 11, 357-383.

Piskunowicz, M., Bieliński, M., Zgliński, A., \& Borkowska, A. (2013). Testy fluencji słownej - zastosowanie w diagnostyce neuropsychologicznej [Verbal fluency tests - application in neuropsychological assessment]. Psychiatria Polska, 47, 475-485.

Raven, J. C. (1991). Test matryc. Wersja standard [Matrices test. Standard version]. Warszawa: Pracownia Testów Psychologicznych Polskiego Towarzystwa Psychologicznego.

Raven, J. C. (2006). The standard progressive matrices - classic version. San Antonio, TX: NCS Pearson, Inc.

Reid, A. A., Szczerbinski, M., Iskierka-Kasperek, E., \& Hansen, P. (2007). Cognitive profiles of adult developmental dyslexics: theoretical implications. Dyslexia, 13, 1-24. https://doi.org/10.1002/dys.321

Reiter, A., Tucha, O., \& Lange, K. W. (2005). Executive functions in children with dyslexia. Dyslexia, 11, 116-131.

Rispens, J., \& Baker, A. (2012). Nonword repetition: the relative contributions of phonological shortterm memory and phonological representations in children with language and reading impairment. Journal of Speech Language and Hearing Research, 55, 683-694. https://doi.org/10.1044/10924388(2011/10-0263)

Sparks, R. L., Patton, J., Ganschow, L., \& Humbach, N. (2012). Relationships among NL print exposure and early NL literacy skills, L2 aptitude, and L2 proficiency. Reading and Writing, 25, 1599-1634. https://doi.org/10.1007/s11145-011-9335-6

Sparks, R. L., Patton, J., Ganschow, L., Humbach, N., \& Javorsky, J. (2006). Native language predictors of foreign language proficiency and foreign language aptitude. Annals of Dyslexia, 56, 129-160. https://doi.org/10.1007/s11881-006-0006-2

Stolarska, U., Kroczka, S., Gergont, A., Steczkowska, M., \& Kaciński, M. (2008). Test fluencji słownej - aspekty rozwojowe w normie i patologii [Verbal fluency test - normal and pathological aspects of development]. Przegląd Lekarski, 65, 764-768.

Sumner, E., Connelly, V., \& Barnett, A. L. (2013). Children with dyslexia are slow writers because they pause more often and not because they are slow at handwriting execution. Reading and Writing: An Interdisciplinary Journal, 26, 991-1008.

Torgesen, J. K., Wagner, R., \& Rashotte, C. (2012). Test of Word Reading Efficiency - Second Edition (TOWRE-2). Austin, TX: PRO-ED.

van Sette, E. R. H., Tops, W., Hakvoort, B. E., van der Leij, A., Maurits, N. M., \& Maassen, B. A. M. (2017). NL and L2 reading skills in Dutch adolescents with a familial risk of dyslexia. PeerJ, 5. https://doi.org/10.7717/peerj.3895

Woźnicki, T., \& Zawadzka, E. (1981). Fazy procesu przyswajania języka obcego [Phases of foreign language acquisition process]. Warszawa: Państwowe Wydawnictwo Naukowe.

Zhao, J., Quiroz, B., Dixon, L. Q., \& Joshi, R. M. (2016). Comparing bilingual to monolingual learners on English spelling: a metaanalytic review. Dyslexia, 22, 193-213. https://doi.org/doi:10.1002/dys. 1530

Zybert, J. (1999). Errors in foreign language learning: the case of Polish learners of English. Warszawa: Instytut Anglistyki Uniwersytetu Warszawskiego. 